Original Article (short paper)

\title{
Impact of a nutrition education program on gymnasts' perceptions and eating practices
}

\author{
Luana Pilon Jürgensen $^{1}$ (D), Natália Vilela Silva Daniel ${ }^{1}$ (D), Ricardo da Costa Padovani $^{2}$ (D), \\ Claudia R Juzwiak ${ }^{3}$ \\ 'Universidade Federal de São Paulo, Pós-Graduação Interdisciplinar em Ciências da Saúde, \\ Santos, SP, Brasil. \\ ${ }^{2}$ Universidade Federal de São Paulo, Departamento de Saúde, Educação e Sociedade, SP, Brasil. \\ ${ }^{\prime}$ Universidade Federal de São Paulo, Departamento de Ciências do Movimento Humano, Santos, \\ SP, Brasil.
}

\begin{abstract}
Aims: To understand how participating in a Nutrition \& Health Education program (NHEP) affected the way rhythm gymnasts and their coaches perceive their food practices. Methods: Qualitative study portraying a case study of a NHEP specifically designed for a rhythm gymnastic team. The NHEP was conducted at the training facilities. Fourteen rhythm gymnasts, consisting of the team that represents a city in the state of São Paulo, Brazil, and their two coaches participated in the study. Athletes and coaches were interviewed about their perceptions and food practices before and after a 9-month NHEP designed specifically for them. Recorded interviews were transcribed verbatim. Two categories emerged from the discourses and were analyzed using the content analysis: "beliefs and feeding practices" and "construction of a positive relationship with food". Results: Athletes reported changes in their food practices related to the themes discussed with them in the NHEP, such as daily breakfast intake, higher intake of fruits, vegetables, milk products, and wholegrain foods. Conclusion: The NHEP allowed specific demands of the athletes to be identified and addressed, generating awareness and motivation to positive changes in eating practices.
\end{abstract}

Keywords: nutrition education, sports nutrition, food behavior.

\section{Introduction}

Nutrition Education is an important strategy for the promotion of healthy food practices, the development of a culture of sustainable consumption and the appreciation of traditional food culture ${ }^{1}$. However, there is scarce information about the planning of educational actions, their possibilities and results in the sports environment, considering that it is a scenario of vulnerability for the adoption of inappropriate food practices, especially among young athletes 2,3 .

National ${ }^{4,5,6}$ and international ${ }^{7,8,9}$ studies that evaluated the quality of the diet showed that athletes' dietary intake presents similar characteristics to those of the general population, with low consumption of fruits and vegetables, milk and dairy products, and high consumption of simple sugar-rich food. In addition, they do not meet specific energy and nutrient recommendations that optimize their athletic performance. Adolescent athletes are more vulnerable to nutritional inadequacies as their needs sum their training and growth demands ${ }^{2,3}$.

The search for an athletic body, more specifically with low body mass and adiposity, is a reality in many sports, but especially in those involving an aesthetic com- ponent, such as rhythmic gymnastics $(\mathrm{RG})^{10}$. The imposition of a lean body and the dietary restrictions, common to the gymnasts, can lead to a distorted perception of their bodies and disordered eating behaviors ${ }^{10,11}$. The aesthetic standard in RG is described as a slender, long-limbed body model, such as the international body standard of highlevel gymnasts who have secured Olympic medals. Analyzing a training day of the Brazilian RG team, Porpino ${ }^{12}$ described the pressure on the athletes to achieve an ideal body mass through daily weighing, which may imply, if they have negative results, the athlete's exclusion from the team and the development of disorders and diseases due to the rigor of weight control may occur.

Food, in addition to its nutritional properties, plays an important sociocultural role. Local and regional food customs acquired at different stages of life have meanings related to psychological, ecological, economic and cultural aspects ${ }^{1,13}$. Other aspects affect athletes' food practices and their body image such as the influence of other athletes, food beliefs, social and coaches' pressure on body image $^{14}$. Furthermore, Martínez Sanz et al. ${ }^{15}$ have shown that the factors influencing food choices in sports start from the introduction of food and habits established dur- 
Table 1 - Topics, educational objectives and strategies adopted in each activity of the NHEP.

\begin{tabular}{|c|c|c|c|}
\hline Meeting & Theme* & Educational objectives & Strategies \\
\hline $1^{\circ}$ & Breakfast & To understand the importance of eating breakfast daily & $\begin{array}{l}\text { "Breakfast hangman" based on the healthy options proposed on the } \\
\text { Food Guide for the Brazilian population }\end{array}$ \\
\hline $2^{\circ}$ & $\begin{array}{l}\text { Food } \\
\text { groups }\end{array}$ & $\begin{array}{l}\text { To know the food groups and how to make substitutions for } \\
\text { healthy meals }\end{array}$ & Hash game using foods images from the correct food groups \\
\hline $3^{\circ}$ & $\begin{array}{l}\text { Food } \\
\text { beliefs }\end{array}$ & To demystify beliefs & $\begin{array}{l}\text { Board game with questions about the beliefs identified in the diag- } \\
\text { nostic activity }\end{array}$ \\
\hline $4^{\circ}$ & $\begin{array}{l}\text { Healthy } \\
\text { snacks }\end{array}$ & $\begin{array}{l}\text { To understand the importance of healthy snacks to achieve } \\
\text { energy needs and the best options in training and competi- } \\
\text { tion situations }\end{array}$ & $\begin{array}{l}\text { Guessing game with food images, equivalent portions of food and } \\
\text { tasting of healthy snack options }\end{array}$ \\
\hline $5^{\circ}$ & $\begin{array}{l}\text { Body } \\
\text { image }\end{array}$ & $\begin{array}{l}\text { To reflect about their body image and the risks of inade- } \\
\text { quate weight loss practices }\end{array}$ & $\begin{array}{l}\text { Using a video in which women were drawn according to the inter- } \\
\text { pretation of two different people, athletes were invited to discuss } \\
\text { about their body composition and image }\end{array}$ \\
\hline
\end{tabular}

${ }^{*}$ All the covered topics were identified through the initial diagnosis.

The NHEP team was composed of 8 undergraduate students and two professors (Psychology and Nutrition). After each activity athletes wrote an evaluation of the activity and indicated their perceptions, intentions of change or what they could adopt in their daily practice.

Finally, in the third stage (final evaluation), all the instruments used in the diagnostic stage were reapplied. Athletes and coaches were interviewed once again, now aiming to assess perceptions and the possible impact of the NHEP on food practices. This took place in two months' time, resulting in five meetings. The quantitative results obtained through the applied questionnaires are in the process of being published elsewhere, so only the results yielded from the interviews, focal group and activities' written evaluations are presented in this study.

\section{Procedures: interviews, focal group, and participant observation}

To ensure validity and scientific rigor we adopted the triangulation strategy, that is, we used multiple methods (interviews, focus groups, and participant observation) and sources (athletes and coaches) ${ }^{27}$.

The interviews conducted before and after the intervention were individually scheduled and had an average duration of 20 minutes. Also, a 3-hour focal group was conducted with all athletes. For both interviews and focal group, a semi-structured script was used with questions regarding sports trajectory, eating practices, sports performance, body image and how they felt participating in the NHEP. The interviews (both individual and group) were recorded and transcribed in full by a single interviewer.

Participant observation allowed us to register all that was discussed and how athletes acted and interacted during activities throughout the NHEP. The interviewer's perceptions and observations were also recorded at the time of the interviews and focus group.

After an in-depth reading of all the transcriptions, the content analysis was performed ${ }^{27}$. After the pre-analysis, when all the transcribed material was explored, key- expressions were identified based on aprioristic categories, which originated the final categories of analysis: "beliefs and feeding practices" and "construction of a positive relationship with food". To ensure athletes' anonymity names were substituted by a code (RG1 to RG14; $\mathrm{C} 1$ and C2).

\section{Results}

Athletes were between 15 and 22 years old and had between 2 and 14 years of sports practice. They practiced 5 days/week, from 4 to 5 hours/day. A male and a female coach, both ex-athletes, were also interviewed.

Sports initiation happened still in childhood and the pressure in relation to body mass/composition and eating practices happened as early as they began to participate in competitive events.

\footnotetext{
I was little, I was 8 years old, and my mother thought it better that I went into some sport because I was getting very fat ... I started to compete in larger competitions, and I began to realize that I was very overweight, that I had to be with the perfect body, then I began to take more care of myself (RG1, 15y).
}

The presence of rigid rules regarding dietary intake and body image related to the sport was evident in all athletes' discourses, which shows that they make their food choices more concerned with body aesthetics than with sports performance or health. It is also observed the influence of external evaluation in the construction of their perception of an ideal body and, consequently, the need to achieve perfection as described in the literature ${ }^{12,14,15}$.

\section{Food beliefs and practices}

In the first stage of the NHEP athletes' discourse revealed several food beliefs related to weight loss goals and performance. The avoidance carbohydrate-rich foods to lose weight was the most frequent, independent of the role of this nutrient on performance. They reported other practices to control their body composition, such as not having lunch or doing sit-ups immediately before a body 
composition assessment to lower fat percentage. They also reported that the best way to decrease body fat is adopting fast weight-loss strategies. It is possible observe the impact of believes in the gymnasts' eating practices.

Gymnasts explained that eating pre-competition "makes them heavier", so in order to feel "lighter", many prefer to fast. Food restriction in the competitive period, both in the days preceding and during the competition, were reported.

My previous coach said that it was not good for us to eat a lot before the competition [...] (RG1, 15y).

The low intake of vegetables, wholegrain food and milk products and the high and frequent intake of sweets, ice-cream, soft drinks and chocolate was also highlighted in theirs discourses.

Another element observed was the "nutritionalization" of the discourse, when athletes refer to the intake of nutrients instead of foods.

[...] sometimes I get home and I'm not going to eat carbohydrates (RG12, 20y).

Another aspect that athletes highlighted in the diagnostic stage was their difficulty in having breakfast due to the lack of habit of for feeling discomfort.

Athletes discourses revealed how the aesthetic aspect of the sport led to pressure from parents, peers, and especially coaches, generating embarrassment and suffering and leading to eating and other practices aimed at losing weight.

[...] If I were thin, I would not have to run so much after training, and I would not be called fat in front of everyone. I feel bad in relation to the other girls because I think they are much thinner than I am $[\ldots]$ (RG13, 19y).

Athletes unite themselves to achieve joint weight goals and create "tasks" for the whole team to lose weight. Despite the suffering expressed in the discourses, this complicity and companionship between them to endure the pressure and to achieve the body mass/composition they desire is seen as positive. This situation shows how complex changing behavior is, especially when the reference group shares the same idea.

We quarrel with each other when someone is eating cake or similar things because she cannot, she's going to be heavy when training (RG4, 18y)

The coaches exert a strong influence on the gymnast's food practices both regarding the restriction of food to reach the aesthetic standard required by the sport discipline as well as regarding the dissemination of food beliefs.

As I was not too chubby, I thought I didn't have to cut on food. But then, after the coach began talking about it I did. That was about 3 months later (RG6, 16y)
The athletes' speeches also highlight the impact of external evaluation and the effect of peers on maintaining behavioral patterns, even if harmful to physical and mental health.

\section{The construction of a positive relationship with food}

Athletes perceived that the NHEP was built based on the reality observed by them at the diagnostic stage, indicating that this stage was important for the identification of topics and the design of activities. Active methodologies, games and ludic activities were considered good strategies ${ }^{28}$ to learn about food and nutrition that brought athletes closer to their reality, allowing them to identify their own problems during the activities. Then they were able to find solutions and plan ways to put into practice what was discussed in each, as proposed by the methodology of the Maguerez $\mathrm{Arch}^{26}$, enhancing their autonomy $^{1,23}$.

We interacted and learned differently, it was not that same boring thing as in school, to learn what one can or cannot. It was dynamic and it was well prepared, so I thought it was cool (RG6, $16 y)$.

The motivation reported by the athletes and the perception that the activities dealt with real issues, suggests that the project proposal was fulfilled, according to the theoretical framework adopted ${ }^{26}$.

The participation in the NHEP had a positive influence on their food practices

[...] I learned a lot from the NHEP. Even my mother says, "Ah, it's wholegrain," and I say, "No. Look at the label, whole wheat flour is not the first ingredient, mother (laugh) (RG3, 20y).

Some athletes were able to report specific dietary changes according to the themes worked during the NHEP, for example: eating breakfast every day or change from industrialized to homemade cookie tasted during one of the activities. Other athletes reported general changes in eating quality, such as substituting fried foods, soft drinks, chocolates, and fast foods for healthier options (e.g. junk food for "real" food, increased vegetables intake).

I'm much more motivated [to eat healthy]. Because when you [referring to the NHEP team] explain everything gets much tastier. Everything is easier to do (RG13, 19y)

The coaches also noticed these changes in athletes' eating practices. They found the strategies used in the activities adequate, facilitating the attention and learning of the athletes.

[...] actually it holds the girls' attention much more. If you kept talking and explaining those classifications and so on, they would give it five minutes of attention and then they would find it annoying. When you are in the middle of a game, they can associate things better $(\mathrm{C} 1)$. 
The coaches also indicated that the NHEP project influenced positively on athlete's motivation to better food practices, especially during trips and competitions:

I can see they have improved, and they make better choices. I noticed a lot of improvement when we talk during our travels, we spend a lot of time together and I realize that their food choices have changed a lot, so I think it was really cool after you came compared to how they ate before (C2).

The athletes' discourses show the importance of learning how to change dysfunctional beliefs and behaviors.

\section{Discussion}

In this study, we sought to understand how athletes, as well as their coaches, perceive their participation in a NHEP and how it affected the way they think about eating and their food practices.

The observed athletic initiation at a very early age and the premature pressure to achieve an "ideal" body composition are also evidenced in other studies on this sports discipline ${ }^{29,30}$. In the case of RG, early sports initiation is justified by the sporting peak, usually occurring in adolescence, and by competition regulations that allow very young children to participate ${ }^{29}$.

Regarding dietary beliefs and practices it was observed that, despite the low consumption of fruits, vegetables, and wholegrain products, these foods were perceived, from the beginning, as good choices for athletes. Although their knowledge and their sports goals, other aspects influenced their food choices, for example, aversions and food preferences, family influence, food availability, organization of mealtimes and regularity in consumption. It was also observed that athletes' discourse is rich in dietary beliefs related to the goals of weight loss and performance ${ }^{31,32}$. According to Juzwiak ${ }^{33}$, these beliefs can be explained by the existence of a gap between the scientific knowledge and the dissemination of information directed to the athlete through social networks and media or by colleagues and unskilled professionals.

The "nutritionalization" in the athletes' speech, that is, when they refer to eating nutrients, not food, represents the substitution of a diet based on habits, tastes, traditions, and rituals by a nutrient-focused diet ${ }^{34,35}$. Scrinis ${ }^{34}$ also highlights as nutritiolization, the prizing of specific foods separately from other foods, diets and broader contexts, tending to classify them as "superfoods" (i.e, sweet-potato and its attribution to increase muscle mass) or "villains", a way of reducing food to its nutrient content. Thus, the nutrient-reducing focus has surpassed the importance of the type and quality of foods and ingredients and has hampered the understanding of their cultural role and the maintenance of traditions ${ }^{34}$.

According to Knapp and Beck ${ }^{36}$, once a belief is formed, it can influence the subsequent formation of new related beliefs and, if they persist, are incorporated into the long-lasting cognitive structure. In addition, beliefs are shaped by personal experiences and derive from identification with other significant people and the perception of other people's attitudes toward the individual ${ }^{36}$. In the case of RG athletes, the entrenched beliefs may be related to the fact that sports initiation happens still in childhood ${ }^{12,29}$ and their main influence from coaches and older athletes is sport focused ${ }^{14,15,37}$.

Studies that used quantitative methodology showed positive changes in athletes' eating practices after Nutrition Education programs. Abood et al. ${ }^{16}$ identified that college football athletes increased the overall number of positive changes in diet and self-efficacy in dietary choices. Schwartz ${ }^{18}$ observed improvement in fruit and vegetable intake, while Molina-Lopez et al. ${ }^{17}$ observed an increase in total energy and macronutrients intake. In this study, we identified how the NHEP generated reflection on food practices and motivated athletes' to changes how they relate to food. The use of strategies that are favorable or unfavorable to learning is directly related to motivation, being fundamental to initiate and maintain the efforts throughout the learning process ${ }^{38}$. According to Brug ${ }^{39}$, behavioral decisions or intentions are recognized as the main determinants of behavior and intentions can be considered a consequence of motivation.

In the present study, the accomplishment of a consistent diagnostic stage allowed us to plan activities based on problem-solving methodologies, important to promote learning on a meaningful basis, starting from the observation of reality, determining the points that represent the observed gaps that triggered a theorizing movement for learning ${ }^{25}$, focused on their reality, promoting their autonomy.

Despite the scarce number of studies with athletes, positive effects similar to those of the present study can be observed in other populations. In a study conducted by Rêgo et $\mathrm{al}^{40}{ }^{40}$ with postgraduate students in the health area, the methodology of the Maguerez Arch was considered adequate, stimulating, innovative and facilitating, making possible the interrelation between students and teachers, as well as between theory and practice.

An effective NHEP cannot be reduced to just transmitting scientific knowledge and practical technical information but must encompass the whole dimension of body, mind, psyche, culture and society, imparting information and concepts considering the life history, the social insertion, culture, and affective meanings related to eating practices, aiming at the well-being, access, and autonomy to healthy food choices ${ }^{1,23}$.

The positive perception of the coaches is also important for the success of the intervention. According to Moraes et $a{ }^{41}{ }^{41}$, the behavior of coaches influence the level of performance of the athletes and is considered crucial for the personal and athletic development of the athletes. The 
influence of the coach goes far beyond sports context, interfering in the athletes' life, development, and personal growth $^{42}$.

Other studies also found that the dissemination of beliefs and pressure to achieve body composition goals by the coaches are factors that influence athletes' dietary choices $^{14,15}$. Coaches are frequently the main sources of nutritional information to athletes because they are the closest professionals due to the daily contact between them $^{37,43}$. In the case of RG, in addition to the daily contact during the long periods of training since early ages, coaches frequently are responsible for the food during competitions and trips.

According to Fortes and Ferreira ${ }^{44}$, the pressure of coaches for better performance and body composition, the use of clothing that emphasizes body shape, where the focus is given to leanness and weight loss are specific factors to the RG environment that potentialize the onset of eating disorders or disordered eating. Athletes are submitted to high training loads, live under high psychological stress, and strict caloric restriction to maintain low body weight, which can lead to alterations in the hormonal profile and menstrual dysfunction ${ }^{30}$. Furthermore, the constant requirement to be thin triggers a process of anxiety and stress about their own body, affecting the psychological dimensions and leading to distortion of body image $^{10}$. These issues were evidenced when gymnasts report sacrificial situations to reach the ideal body for the sporting modality.

Therefore, deepening the understanding of the set of representations and meanings involved in athletes' food choices and the socioeconomic and cultural aspects are fundamental for the development of effective interventions in their daily lives ${ }^{23,33}$.

\section{Conclusion}

Athletes and coaches'perception indicate that participation in an NHEP intervention had positive effects on athletes' awareness, and motivation to change their food practices. NHEP must be designed according to the needs of each group, considering the sport's nutritional demands as well as socio-cultural aspects.

\section{References}

1. Brasil. Ministério do Desenvolvimento Social e Combate à Fome. Secretaria Nacional de Segurança Alimentar e Nutricional. Marco de referência de Educação Alimentar e Nutricional para as políticas públicas. Brasília: MD, 2012.

2. Desbrow B, Mccrmack J, Burke LM, Cox GR, Fallon K, Hislop M, et al. Sports Dietitians Australia declaração de posição: nutrição esportiva para o atleta adolescente. Int J Sport Nutr Exerc Metab. 2014; 24(5):570-84.
3. Bingham ME, Borkan ME, Quatromoni, PA. Sports nutrition advice for adolescent athletes: a time to focus on food. Am J Lifestyle Med. 2015; 9(6):389-402.

4. Bissochi CO, Juzwiak CR. Avaliação nutricional e da percepção da autoimagem corporal de atletas adolescentes de voleibol. Nutrire. 2012;37(1):34-53.

5. Jürgensen LP, Daniel NVS, Padovani RC, Lourenço LCD, Juzwiak CR. Assessment of the diet quality of team sports athletes. Rev Bras Cineantropom Desemp Hum. 2015;17 (3):280-290.

6. Santos D, Silveira IQ, Cesar TB. Nutritional intake and overall diet quality of female soccer players before the competition period. Rev Nutr. 2016;2(4):555-565.

7. Weber MH, Kehl C, Moreira JCF. Comparação do perfil dietético e antropométrico de atletas de handebol durante um período de treinamento. FIEP Bulletin. 2012;82 Special Edition - Article II; Available at: http://www.fiepbulletin. net. Accessed in February 10, 2015.

8. Grijota-Pérez FJ, Barrientos VG, Casado-Dorado A, Muñoz-Marín D, Robles Gil MC, Maynar-Mariño M. Análisis nutricional em atletas de fondo y médio fondo durante uns temporada desportiva. Nutr Hosp. 2016;33(5):11361141.

9. Günay E, Gülgün E. An evaluation of wheelchair basketball players nutritional status and nutritional knowledge levels. J Sports Med Phys Fitness. 2016;56(3):259-268.

10. Vieira JLL, Amorim HZ, Vieira LF, Amorim AC, Rocha PGM. Distúrbios de atitudes alimentares e distorção da imagem corporal no contexto competitivo da ginástica rítmica. Rev Bras Med Esporte. 2009;15(6):410-414.

11. Kosmidou E, Proios M, Doganis G, Douda HT. Evaluation of an intervention program on body esteem, eating attitudes and pressure to be thin in rhythmic gymnastics athletes. Science of Gymnastics Journal. 2015; (3):23-36.

12. Porpino KO. Treinamento da Ginástica Rítmica: Reflexões Estéticas. Psic Rev 2017; 26(1):187-209.

13. Garcia RWD. Antropologia Aplicada às diferentes áreas de Nutrição. In: Canesqui, A.M. Antropologia e Nutrição: um diálogo possível. Rio de Janeiro: Editora FIOCRUZ, 2005. 306p.

14. Heaney S, O'Connor H, Naughton G, Gofford J. Towards an understanding of the barriers to good nutrition for elite athletes. Int J Sports Sci Coaching. 2008; 3(3):391-401.

15. Martínez Sanz JM, Undampilleta A, Micó L, Soriano JM. Aspectos psicológicos y sociológicos en la alimentación de los desportistas. Cuad Psicol Deporte. 2012;12(2):39-48.

16. Abood DA, Black DR, Birnbaum RD. Nutrition Education intervention for college female athletes. J Nutr Educ Behav. 2004;36(3):135-139.

17. Molina-López J, Molina JM, Chirosa LJ, Florea D, Sáez L, Jiménez J, Planells P, et al. Implementation of a nutrition education program in a handball team; consequences on nutritional status. Nutr Hosp. 2013; 28:1065-1076.

18. Schwartz AK. The effect of a nutrition education program on nutrition knowledge, dietary intake, body composition and perceived sport performance among high school athletes. [Master of Science] - University of Kentucky, 2014.

19. Buffington BC, Melnyk BM, Morales S, Lords A, Zupan MR. Effects of an energy balance educational intervention 
and the COPE cognitive behavioral therapy intervention for Division I U.S. Air Force Academy female athletes. J Am Assoc Nurse Pract. 2016; 28(4):181-184.

20. Daniel NV, Jürgensen LP, Padovani RC, Juzwiak CR. Impact of an interdisciplinary food, nutrition and health education program for adolescent Brazilian volleyball players. Rev Nutr. 2016;29(4):567-577.

21. Beggs VCE, Nolte VW, Dickey JP. The impact of nutritional counseling in conjunction with co-active coaching on behavior change of varsity female rowers. Sports Nutr Ther. 2016;1(3):1-8

22. Coccia C, Fernandes SM, Altit I. Tweeting for nutrition: feasibility and efficacy outcomes of a 6-week social mediabased nutrition education intervention for student-athletes. $\mathrm{J}$ Strength Cond Res. 2018.

23. Boog MCF. Educação em Nutrição: integrando experiências. Campinas, São Paulo: Komedi, 268p, 2013.

24. Mello CM. Abordagens e procedimentos qualitativos: implicações para pesquisas em organizações. Rev. Alcance. 2014; 21(2):324-349.

25. Maia JA. Metodologias problematizadoras em currículos de graduação médica. Rev. Bras Educ Méd. 2014;38(4).

26. Berbel NAN, Gamboa SAA. A metodologia da problematização com o Arco de Maguerez: uma perspectiva teórica e epistemológica. Filosofia e Educação (Online). 2012; 3(2):264-287.

27. Minayo MCS. O desafio do conhecimento. Pesquisa qualitativa em saúde. São Paulo: Hucitec, 2010.

28. Vale LR, Oliveira MFA. Atividades lúdicas sobre educação nutricional como incentivo à alimentação saudável. Revista Práxis. 2016;18(1 Supl):107-114.

29. Nunomura M, Carrara PDS, Tsukamoto MHC. Ginástica artística e especialização precoce: cedo demais para especializar, tarde demais para ser campeão! Rev Bras Educ Fís Esporte. 2010;24(3):305-314.

30. Coelho SMH, Simões RD, Lunz W. Desequilibrio hormonal e disfunção menstrual em atletas de ginástica rítmica. Rev Bras Ciênc Esporte. 2015;37(3):222-229.

31. Pereira JMO, Cabral P. Avaliação dos conhecimentos bási$\cos$ de nutrição de praticantes de musculação em uma cidade de Recife. Rev Bras Nutr Esport. 2007;1(1):40-47.

32. Amorim SF. Impacto da educação alimentar nos conhecimentos de nutrição e alimentação e na ingestão nutricional de jovens futebolistas. [Trabalho de Investigação] - Universidade do Porto. Porto, 2008.

33. Juzwiak CR. Reflection on sports nutrition: where we come from, where we are headed. Rev Nutr. 2016; 29(3):435-444.

34. Scrinis G. On the ideology of nutritionism gastronomic. J Food Culture. 2008; 8(1):39-41, 200

35. Serra R, Gregório MJ, Graça P. Produção compartilhada de conhecimentos nas ciências da nutrição, ciências sociais e saúde. Oficina do Centro de Estudos Sociais $n^{\circ} 372$, Universidade de Coimbra, 2011.

36. Knapp P, Beck AT. Fundamentos, modelos conceituais, aplicações e pesquisa da terapia cognitiva. Rev Bras Psiquiatr. 2008;30(supl.2):s54-s64.

37. Juzwiak CR, Ancona-Lopez F. Evaluation of nutrition knowledge and dietary recommendations by coaches of adolescent Brazilian athletes. Int J Sport Nutr Exerc Metab. 2004; 14:222-235.

38. Ganda DR, Boruchovitch E. Promoting self-regulated learning of Brazilian preservice student teachers: results of an intervention program. Frontiers in Education. 2018; 3(1).

39. Brug J. Determinantes da alimentação saudável: motivação, habilidades e Oportunidades ambientais. Fam Pract. 2018; 25(1).

40. Rêgo JTP, Silva TAL, Medeiros RMV, Barboza RR, Medeiros JÁ, Dantas PMS, Miranda HF. Conhecimento Nutricional e estado antropométrico de atletas universitários. Rev. Bras. Med. Esporte. 2015; 21(6):447-450.

41. Moraes LCCA, Medeiros-Filho ES, Lôbo ILB, Silveira DR. Escala do comportamento do treinador - versão treinador (ECT-T) e versão atleta (ECT-A): o que o treinador diz é confirmado por seus atletas? Rev Bras Educ Fis Esporte. 2010; 24(1):37-47.

42. Cruz JFA, Gomes AE, Dias CS. Promoção da relação treinador-atletas na formação desportiva: eficácia de intervenções psicológicas no handebol. Psicologia: teoria, investigação e prática. 1997; 2(3):587-609.

43. Chagas BF, Nascimento MVS, Raposo OFF, Mendes-Netto RS. Treinadores apresentam maior conhecimento em nutrição básica que em nutrição esportiva. Rev Bras Nutr Esport. 2016;10(60):627-636.

44. Fortes LS, Ferreira MEC. Comparação da insatisfação corporal e do comportamento alimentar inadequado em atletas adolescentes de diferentes modalidades esportivas. Rev Bras Educ Fís Esporte. 2011;25(4):707-716.

\section{Corresponding author}

Natália Vilela Silva Daniel: Street Silva Jardim, 136 - Vila Mathias, Santos, SP, Brasil.

E-mail: natalia.vilelasd@gmail.com.

Manuscript received on November 19, 2019

Manuscript accepted on February 16, 2020

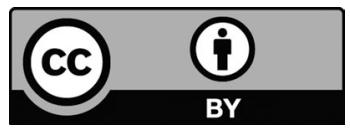

Motriz. The Journal of Physical Education. UNESP. Rio Claro, SP, Brazil - eISSN: 1980-6574 - under a license Creative Commons - Version 4.0 